\title{
History of thyroid disease and survival of ovarian cancer patients: results from the Ovarian Cancer Association Consortium, a brief report
}

Albina N Minlikeeva ${ }^{1}$, Jo L Freudenheim ${ }^{2}$, Rikki A Cannioto ${ }^{1}, K_{\text {Kevin H Eng }}{ }^{3}$, J Brian Szender ${ }^{4}$, Paul Mayor ${ }^{4}$, John L Etter ${ }^{1}$, Daniel W Cramer ${ }^{5}$, Brenda Diergaarde ${ }^{6}$, Jennifer A Doherty ${ }^{7}$, Thilo Dörk ${ }^{8}$, Robert Edwards ${ }^{9,10}$, Anna deFazio ${ }^{11,34}$, Grace Friel ${ }^{1}$, Marc T Goodman ${ }^{12}$, Peter Hillemanns ${ }^{8}$, Estrid Høgdall ${ }^{13,14}$, Allan Jensen ${ }^{13}$, Susan J Jordan ${ }^{15}$, Beth Y Karlan ${ }^{16}$, Susanne K Kjær ${ }^{13,17}$, Rüdiger Klapdor ${ }^{8}$, Keitaro Matsuo ${ }^{18}$, Mika Mizuno ${ }^{19}$, Christina M Nagle ${ }^{15,20}$, Kunle Odunsi ${ }^{4,21}$, Lisa Paddock ${ }^{22,23}$, Mary Anne Rossing ${ }^{24}$, Joellen M Schildkraut ${ }^{25}$, Barbara Schmalfeldt ${ }^{26}$, Brahm H Segal ${ }^{27,28}$, Kristen Starbuck ${ }^{4}$, Kathryn L Terry ${ }^{5}$, Penelope M Webb ${ }^{15}$, Emese Zsiros ${ }^{21}$, Roberta B Ness ${ }^{29}$, Francesmary Modugno 9,10,30, Elisa V Bandera ${ }^{31}$, Jenny Chang-Claude ${ }^{32,33}$ and Kirsten B Moysich ${ }^{* 1,2,27}$ on behalf of the Ovarian Cancer Association Consortium

Background: Findings from in vitro studies suggest that increased exposure to thyroid hormones can influence progression of ovarian tumours. However, epidemiologic evidence on this topic is limited.

Methods: We pooled data from 11 studies from the Ovarian Cancer Association Consortium. Using multivariate Cox proportional hazards models, we estimated associations between hyper- and hypothyroidism and medications prescribed for these conditions with 5-year all-cause survival among women diagnosed with invasive ovarian cancer.

Results: Overall, there was a nonsignificant association with history of hyperthyroidism ( $n=160$ cases) and mortality (HR=1.22; $95 \% \mathrm{Cl}=0.97-1.53)$. Furthermore, diagnosis of hyperthyroidism within the 5 years before ovarian cancer diagnosis was associated with an increased risk of death $(H R=1.94 ; 95 \% \mathrm{Cl}=1.19-3.18)$. A more modest association was observed with history of hypothyroidism ( $n=624$ cases) and mortality $(\mathrm{HR}=1.16 ; 95 \% \mathrm{Cl}=1.03-1.31)$. Neither duration of hypothyroidism nor use of thyroid medications was associated with survival.

Conclusions: In this large study of women with ovarian cancer, we found that recent history of hyperthyroidism and overall history of hypothyroidism were associated with worse 5-year survival.

Ovarian cancer is the most deadly gynaecological cancer with 5year survival rate of $\sim 46 \%$ (Siegel et al, 2017). Some previous epidemiologic studies have shown that hormonal factors, including hormone therapy (HT) and cortisol, can impact mortality
(Rodriguez et al, 1995; Mascarenhas et al, 2006; Schrepf et al, 2015).

In addition to HT and cortisol, there is recent evidence that exposure to thyroid hormones may also play a role in ovarian

\footnotetext{
*Correspondence: Dr KB Moysich; E-mail: kirsten.moysich@roswellpark.org

${ }^{34}$ On behalf of the Australian Ovarian Cancer Study Group.
}

Received 24 March 2017; revised 17 July 2017; accepted 19 July 2017; published online 17 August 2017

(C) 2017 Cancer Research UK. All rights reserved 0007-0920/17 
cancer progression. An in vitro study has demonstrated that $3,5,3^{\prime}$ triiodo-L-thyronine $\left(\mathrm{T}_{3}\right)$ and L-thyroxine $\left(\mathrm{T}_{4}\right)$ hormones at physiological levels are able to initiate proliferation and improve survival of ovarian cancer cells, whereas exposure to these hormones at concentrations below normal serum levels may result in slower growth of ovarian cancer cells (Shinderman-Maman et al, 2015). The results of the only epidemiologic study that assessed the association between thyroid disease and ovarian cancer mortality were suggestive of a possible link between hyperthyroidism and mortality among these patients (Journy et al, 2017). However, the study was based on a very small number of cases.

We evaluated associations between history of hyper- and hypothyroidism and all-cause mortality using a large international study of women diagnosed with ovarian cancer.

\section{MATERIALS AND METHODS}

We pooled data on history of hyper- and hypothyroidism from the studies participating in the Ovarian Cancer Association Consortium (OCAC). Of all the studies in OCAC, 11 included data on history of hyperthyroidism and 10 on hypothyroidism. All participants provided informed consent; and study protocols were approved by the institutional review boards or ethics committees for each study site. Characteristics of the studies included in this pooled analysis are presented in Table 1. Although most of the data were based on self-report, three studies (HJO, HOP, and LAX) included data collected from medical records. Almost all the studies, except for JPN, provided information on the age at diagnosis with either of these diseases, and four studies (HJO, LAX, NEC, and NJO) also collected information on use of medications prescribed for these conditions including radioactive iodine, antithyroid agents, and thyroid hormones.

Our final study population included patients diagnosed with epithelial invasive ovarian, peritoneal, or fallopian tube cancers. Among these women, 5198 had information on history of hyperthyroidism and 5662 had information on history of hypothyroid disease (yes/no). Hyperthyroidism was defined as any hyperthyroid disease, including Grave's disease, and hypothyroidism as any hypothyroid disease, including Hashimoto's disease.

An additional exposure of interest was time since being diagnosed with these thyroid conditions before the date of diagnosis of ovarian cancer. This was calculated by subtracting age at the time of being diagnosed with either hyper- or hypothyroid disease from the age of diagnosis with ovarian cancer. We then dichotomised this variable using the 5 years as the cutpoint. Another exposure of interest was the use of medications prescribed for hyper- or hypothyroid disease, dichotomised as yes/no. The outcome of interest was overall survival (OS) after ovarian cancer diagnosis censored at 5 years of follow-up defined as the time period between the date of diagnosis and the date of death, date of last contact, or 5 years after the date of diagnosis, whichever occurred first. Additional outcome of interest was survival censored at 10 years of follow-up.

We used age-, stage-, and site-adjusted Cox proportional hazards models to estimate associations between each of these exposures and all-cause mortality by calculating hazard ratios (HRs) and corresponding 95\% confidence intervals (CIs). We also adjusted the models for each of the descriptive and disease characteristics indicated in Table 2. However, because such adjustment did not change the age-, stage-, and site-adjusted associations by $>10 \%$, none of these covariates were included in the final models.

We assessed statistical heterogeneity between study-specific HRs using $I^{2}$ statistics and Cochran's Q-statistics (Higgins et al, 2003).
No heterogeneity was observed, and therefore we estimated and reported pooled HRs and 95\% CIs.

Furthermore, we examined whether associations differed between strata of histotype (serous $v s$ non-serous), BMI $\left(18.5 \mathrm{~kg} \mathrm{~m}^{-2}<\mathrm{BMI}<25.0 \mathrm{~kg} \mathrm{~m}^{-2}\right.$ vs BMI $\left.\geqslant 25.0 \mathrm{~kg} \mathrm{~m}^{-2}\right)$, age at diagnosis ( $<65 v s \geqslant 65$ years), and stage of disease (local/regional $v s$ distant). Presence of multiplicative interaction was examined by including cross-product terms between the exposures of interest and potential effect modifiers (histotype, BMI, age at diagnosis, and stage of disease) and utilising likelihood ratio tests to assess significance of these terms. We additionally accounted for left truncation in all the models to take into consideration time between the date of ovarian cancer diagnosis and date of the interview and the inability to enroll women who had died before the recruitment date.

Finally, we conducted additional analyses after excluding patients who reported history of both hyper- and hypothyroid disease $(n=23)$. For medication use, we also conducted separate analyses limited to patients with a corresponding thyroid disease.

All statistical tests used in the analyses were two sided; $P$-values of $<0.05$ were considered significant.

\section{RESULTS}

Descriptive and clinical characteristics of the participants according to thyroid disease status are presented in Table 2. Participants diagnosed with hyperthyroidism or hypothyroidism were more likely to be older and postmenopausal. Those with history of hypothyroidism were also more likely to be white, obese, more educated, and have a history of hysterectomy, and less likely to breastfeed. Median follow-up times from ovarian cancer diagnosis for patients with neither hypo- nor hyperthyroid disease, patients with hyperthyroidism, and patients with hypothyroidism were 1791, 1574, and 1459 days, respectively.

We observed a positive association between history of hyperthyroidism and overall mortality censored at 5 years of follow-up in the overall sample of patients diagnosed with ovarian cancer, although this association was not statistically significant $(\mathrm{HR}=1.22 ; 95 \% \mathrm{CI}=0.97-1.53$; Table 3$)$. In strata defined by time since diagnosis, only hyperthyroid disease diagnosed within 5 years of ovarian cancer diagnosis was associated with increased mortality $(\mathrm{HR}=1.94 ; 95 \% \mathrm{CI}=1.19-3.18)$. History of hypothyroidism was associated with a slight increased risk of death $(\mathrm{HR}=1.16 ; 95 \%$ $\mathrm{CI}=1.03-1.32$ ). No association was observed between time since diagnosis of hypothyroidism and mortality. For 10-year survival, HRs were slightly attenuated and, for hypothyroidism and duration of hyperthyroidism of 5 years or less before ovarian cancer diagnosis, were no longer statistically significant.

Ever use of anti-hyper- or anti-hypothyroid medications was also not associated with mortality $(\mathrm{HR}=0.69 ; 95 \% \mathrm{CI}=0.17-2.80$ and $\mathrm{HR}=1.04 ; 95 \% \mathrm{CI}=0.77-1.40$, respectively). The associations were not modified by histotype, BMI, age at diagnosis of ovarian cancer, or stage of disease. For medications, conducting analysis among individuals with a corresponding thyroid disease did not considerably influence the observed associations. Accounting for left truncation did not considerably change the HRs observed in the main analysis.

\section{DISCUSSION}

In this large study, we found that recent history of hyperthyroidism and overall history of hypothyroidism were associated with increased 5-year all-cause mortality among ovarian cancer patients. 
Table 1. Characteristics of studies included in the analysis: Ovarian Cancer Association Consortium ${ }^{\mathrm{a}}$

\begin{tabular}{|c|c|c|c|c|c|c|c|}
\hline Study acronym & Study name & $\begin{array}{l}\text { Study } \\
\text { location, } \\
\text { time of } \\
\text { enrolment }\end{array}$ & $\begin{array}{l}\text { Data } \\
\text { collection } \\
\text { method }\end{array}$ & $\begin{array}{l}\text { Median time of } \\
\text { follow-up, days } \\
\text { (range of } \\
\text { follow-up) }\end{array}$ & $\begin{array}{l}\text { Determination of } \\
\text { history of hyper/ } \\
\text { hypothyroidism }\end{array}$ & $\begin{array}{l}\text { Patients with } \\
\text { hyperthyroid } \\
\text { disease, } \\
N(\%)\end{array}$ & $\begin{array}{l}\text { Patients with } \\
\text { hypothyroid } \\
\text { disease, } \\
N(\%)\end{array}$ \\
\hline AUS (Merritt et al, 2008) & $\begin{array}{l}\text { Australian Ovarian } \\
\text { Cancer Study }\end{array}$ & $\begin{array}{l}\text { Australia, } \\
\text { Jan } 2002 \text { to Jun } \\
2006\end{array}$ & $\begin{array}{l}\text { Self-completed } \\
\text { questionnaire }\end{array}$ & 1705 (19-3672) & $\begin{array}{l}\text { Q: Ever having disease requiring } \\
\text { regular medical care }\end{array}$ & $10(0.9)$ & $27(2.3)$ \\
\hline $\begin{array}{l}\text { DOV (Rossing et al, } \\
\text { 2007; Bodelon et al, } \\
\text { 2012) }\end{array}$ & $\begin{array}{l}\text { Disease of the Ovary and } \\
\text { their Evaluation Study }\end{array}$ & $\begin{array}{l}\text { USA: } \\
\text { Washington, } \\
\text { 2002-2005 } \\
\text { (DOV) } \\
\text { 2006-2009 } \\
\text { (DVE) }\end{array}$ & In-person interview & $1398(243-3192)$ & $\begin{array}{l}\text { Q: Disease diagnosed by } \\
\text { physician or health care } \\
\text { professional before being } \\
\text { diagnosed with ovarian cancer }\end{array}$ & $13(2.6)$ & $100(16.7)$ \\
\hline GER (Royar et al, 2001) & $\begin{array}{l}\text { German Ovarian Cancer } \\
\text { Study }\end{array}$ & $\begin{array}{l}\text { Germany, } \\
1993-1996\end{array}$ & $\begin{array}{l}\text { Self-administered } \\
\text { questionnaire }\end{array}$ & $1464(18-6060)$ & $\begin{array}{l}\text { Q: Ever having disease } \\
\text { diagnosed by physician }\end{array}$ & $10(4.4)$ & $7(3.1)$ \\
\hline $\begin{array}{l}\text { HAW (Goodman et al, } \\
\text { 2008; Lurie et al, 2008) }\end{array}$ & $\begin{array}{l}\text { Hawaii Ovarian Cancer } \\
\text { Study }\end{array}$ & $\begin{array}{l}\text { USA: } \\
\text { Hawaii, } \\
\text { 1993-2008 }\end{array}$ & In-person interview & $2750(143-7662)$ & $\begin{array}{l}\text { Q: Disease diagnosed by } \\
\text { physician before being } \\
\text { diagnosed with ovarian cancer }\end{array}$ & $22(4.6)$ & $25(5.2)$ \\
\hline HJO (Song et al, 2009) & $\begin{array}{l}\text { Hannover-Jena Ovarian } \\
\text { Cancer Study }\end{array}$ & $\begin{array}{l}\text { Germany } \\
2007-2011\end{array}$ & MRR & 707 (9-8722) & MRR: reporting of disease & $7(5.4)$ & $29(19.1)$ \\
\hline $\begin{array}{l}\text { HOP (Lo-Ciganic et al, } \\
\text { 2012) }\end{array}$ & $\begin{array}{l}\text { Hormones and Ovarian } \\
\text { Cancer Prediction Study }\end{array}$ & $\begin{array}{l}\text { USA: } \\
\text { Pennsylvania, } \\
\text { Ohio, and } \\
\text { New York, } \\
\text { 2003-2009 }\end{array}$ & $\begin{array}{l}\text { In-person interview } \\
\text { and MRR }\end{array}$ & $1821(40-3982)$ & $\begin{array}{l}\text { Q: Disease diagnosed by } \\
\text { physician or health care } \\
\text { professional before being } \\
\text { diagnosed with ovarian cancer; } \\
\text { MRR: reporting of disease }\end{array}$ & $25(4.2)$ & $109(16.1)$ \\
\hline $\begin{array}{l}\text { JPN (Hamajima et al, } \\
\text { 2001) }\end{array}$ & $\begin{array}{l}\text { Hospital-based Research } \\
\text { Program at Aichi Cancer } \\
\text { Center }\end{array}$ & $\begin{array}{l}\text { Japan, } \\
\text { 2001-2005 }\end{array}$ & In-person interview & $1069(43-3396)$ & Q: Ever having disease & $2(3.1)$ & 0 \\
\hline LAX & $\begin{array}{l}\text { Women's Cancer } \\
\text { Program at the Samuel } \\
\text { Oschin Comprehensive } \\
\text { Cancer Institute }\end{array}$ & $\begin{array}{l}\text { USA: } \\
\text { California, } \\
1989 \text { to present }\end{array}$ & MRR & 1498 (13-8239) & MRR: reporting of disease & $3(1.1)$ & $56(17.3)$ \\
\hline $\begin{array}{l}\text { NCO (Schildkraut et al, } \\
2008,2010)\end{array}$ & $\begin{array}{l}\text { North Carolina Ovarian } \\
\text { Cancer Study }\end{array}$ & $\begin{array}{l}\text { USA: } \\
\text { North Carolina, } \\
\text { 1999-2008 }\end{array}$ & $\begin{array}{l}\text { Self-completed } \\
\text { questionnaire }\end{array}$ & $1836(93-5730)$ & $\begin{array}{l}\text { Q: Disease diagnosed by } \\
\text { physician before being } \\
\text { diagnosed with ovarian cancer }\end{array}$ & $32(3.9)$ & $133(14.3)$ \\
\hline $\begin{array}{l}\text { NEC (Terry et al, 2005; } \\
\text { Merritt et al, 2013) }\end{array}$ & $\begin{array}{l}\text { New England } \\
\text { Case-Control Study of } \\
\text { Ovarian Cancer }\end{array}$ & $\begin{array}{l}\text { USA: } \\
\text { New Hampshire } \\
\text { and } \\
\text { Massachusetts, } \\
\text { 1992-2003 }\end{array}$ & In-person interview & 2904 (70-7709) & $\begin{array}{l}\text { Q: Ever having disease before } \\
\text { being diagnosed with ovarian } \\
\text { cancer }\end{array}$ & $25(3.3)$ & $97(11.6)$ \\
\hline $\begin{array}{l}\text { NJO (Bandera et al, } \\
\text { 2011; Chandran et al, } \\
\text { 2011; Gifkins et al, } \\
\text { 2012) }\end{array}$ & $\begin{array}{l}\text { New Jersey Ovarian } \\
\text { Cancer Study }\end{array}$ & $\begin{array}{l}\text { USA: } \\
\text { New Jersey, } \\
\text { 2002-2008 }\end{array}$ & Phone interview & $2375(165-4085)$ & $\begin{array}{l}\text { Q: Disease diagnosed by health } \\
\text { care professional before being } \\
\text { diagnosed with ovarian cancer }\end{array}$ & $11(5.4)$ & $41(17.7)$ \\
\hline \multicolumn{8}{|c|}{$\begin{array}{l}\text { Abbreviations: MRR = medical record review; } Q=\text { question. } \\
\text { a JPN did not provide information on the age at being diagnosed with hyper- or hypothyroid disease; } L A X \text { did not provide information on the age at being diagnosed with hyperthyroidism; AUS } \\
\text { patients were not specifically asked about thyroid disease, and thyroid disease history was determined from the answers to the open-ended question on having other diseases; HJO, LAX, NEC }\end{array}$} \\
\hline
\end{tabular}

This increased mortality associated with hyperthyroidism may be explained by the biological activity of thyroid hormones. One of these hormones, $\mathrm{T}_{3}$, has been shown to promote expression of genes associated with inflammation including cyclooxygenase-2 and matrix metalloproteinase-9 (Rae et al, 2007), both of which can play a role in tumour invasion or angiogenesis (Lee et al, 2006; $\mathrm{Hu}$ et al, 2012). In one preclinical study, both $\mathrm{T}_{3}$ and $\mathrm{T}_{4}$ inhibited transcription of genes involved in tumour suppression, GDF-15 and IGFBP-6, and cell cycle, p21 and p16 (Shinderman-Maman et al, 2015), thereby influencing proliferation and survival of ovarian cancer cells. A recent increase in exposure to these hormones may result in increased proliferation and invasiveness of ovarian tumours and, consequently, impact survival of ovarian cancer patients, possibly explaining the association observed in our study.

Out of the four studies conducted to examine the link between thyroid disease and ovarian cancer (Ness et al, 2000; Brinton et al, 2007; Kang et al, 2013), only one was conducted to assess the association with survival (Journy et al, 2017). Similarly to us, the authors of the survival study concluded that there was a suggestion of the association between hyperthyroidism and mortality among ovarian cancer patients (Journy et al, 2017). However, our study was considerably larger; we were also able to control for important prognostic factors.

We found that overall history of hypothyroidism was also associated with a slightly increased mortality. This finding is different from what we had expected based on the in vitro finding that thyroid hormones below biologically normal levels slow growth of ovarian cancer cells (Shinderman-Maman et al, 2015). There are several possible explanations for our observation. One treatment for hyperthyroidism is radioiodine therapy; this treatment can result in transient or permanent hypothyroidism in patients (Burch and Cooper, 2015). The observed decreased 5-year survival that we found associated with hypothyroidism could be the result of previous hyperthyroidism. In our study population, however, exclusion of 23 patients with history of both hyper- and hypothyroidism from the analysis did not change the observed estimates.

Another possible explanation is that external thyroid hormones prescribed for hypothyroidism might be in excess of what is physiologically required or that treatment regimens do not replicate normal secretion patterns. This excessive exposure to 
Table 2. Demographic and disease characteristics of ovarian cancer patients, Ovarian Cancer Association Consortium ${ }^{\mathrm{a}}$

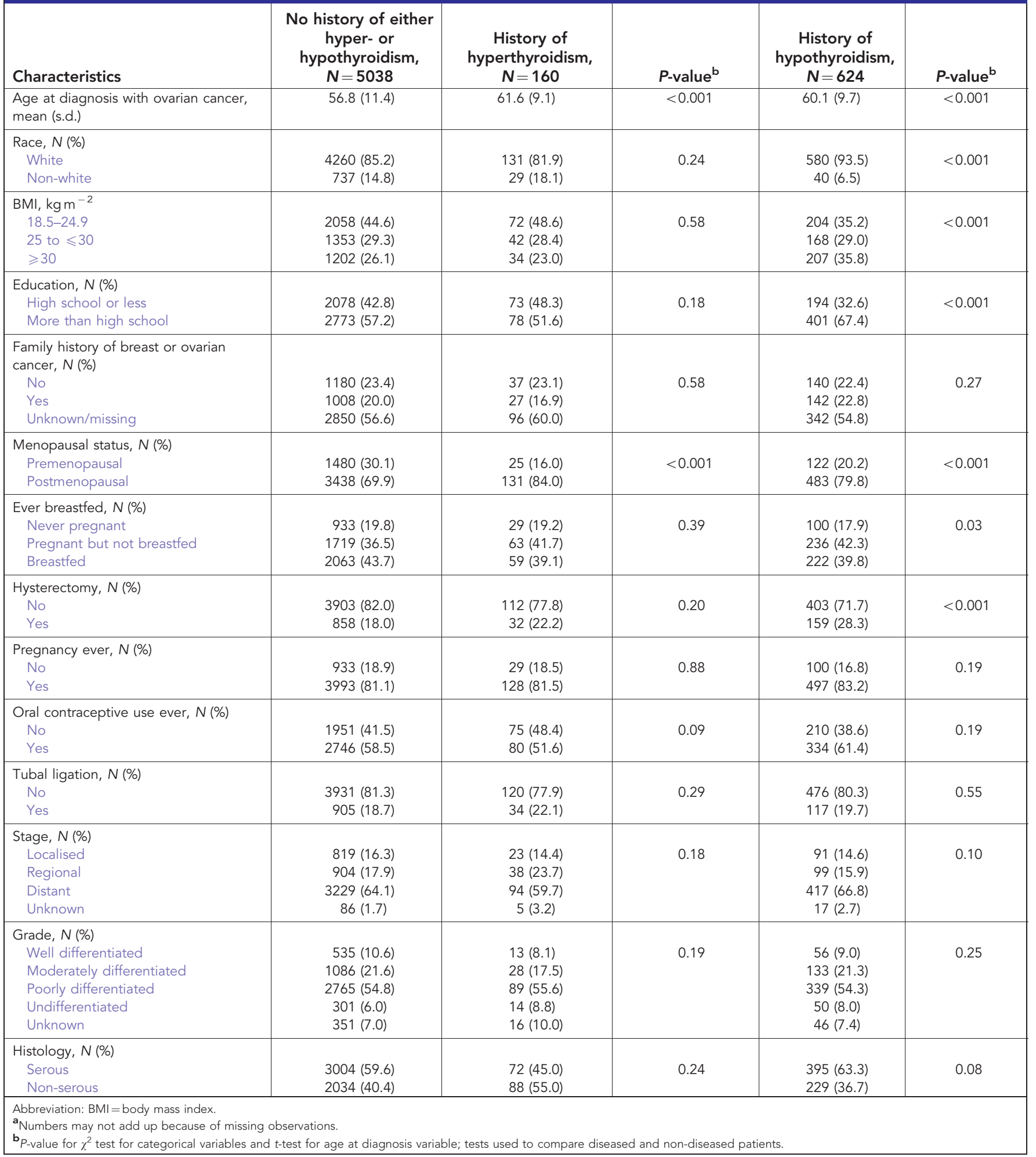

thyroid hormone, therefore, can result in activation of the biological processes described above. We did not observe any association between intake of thyroid hormones and survival. However, it could be that duration and timing of thyroid hormone intake are more important than the overall exposure to thyroid hormones. Data on timing of thyroid hormone replacement were not available to us; therefore, we were not able to explore these associations further.
In interpreting of this study, understanding of the strengths and weaknesses is critical. Important strengths include a large study size allowing us to examine main effects as well as associations within strata of potential effect modifiers. Because ovarian cancer is relatively rare, pooled data such as these are critical for a more detailed examination of factors related to survival. Limitations of the study include reliance on self-report of hyper- and hypothyroidism rather than medical reports or even actual measurement of 
Table 3. Association between history of hyperthyroidism and hypothyroidism and 5-year overall survival following a diagnosis of invasive ovarian cancer, Ovarian Cancer Association Consortium

\begin{tabular}{|c|c|c|c|c|}
\hline & Dead & Alive & $\operatorname{HR}(95 \% \mathrm{Cl})^{\mathrm{a}}$ & $P$-value \\
\hline No history of hyper-or hypothyroidism & 2206 & 2832 & 1.00 (Ref) & \\
\hline History of hyperthyroidism & 80 & 80 & $1.22(0.97-1.53)$ & 0.08 \\
\hline History of hypothyroidism & 315 & 309 & $1.16(1.03-1.31)$ & 0.01 \\
\hline $\begin{array}{l}\text { Use of hyperthyroid medications } \\
\text { No } \\
\text { Yes }\end{array}$ & $\begin{array}{c}360 \\
6\end{array}$ & $\begin{array}{c}306 \\
5\end{array}$ & $\begin{array}{l}1.00 \text { (Ref) } \\
0.69(0.17-2.80)\end{array}$ & 0.61 \\
\hline
\end{tabular}

$\mathrm{T}_{3}$ and $\mathrm{T}_{4}$ hormones. Moreover, there is a possibility that our finding can be explained by chance only or by the presence of residual confounding because of our inability to control for treatment after ovarian cancer diagnosis. Finally, the outcome of interest was all-cause mortality instead of ovarian cancerspecific mortality. However, as shown in other OCAC survival studies, among these patients, most deaths are likely to be attributable to ovarian cancer (Cannioto et al, 2016; Minlikeeva et al, 2017).

Nonetheless, our findings potentially could have important clinical implications in relation to prognosis of ovarian cancer among women diagnosed with hyper- or hypothyroid diseases if validated in other studies. Clinicians may need to be aware of the fact that ovarian cancer patients with history of thyroid disease, particularly hyperthyroidism, can experience worse prognosis compared with patients without such history. It could also be important to monitor and correct thyroid hormones levels at the time of diagnosis with ovarian cancer.

Future studies need to confirm whether history of thyroid disease influences survival outcomes among ovarian cancer patients.

\section{ACKNOWLEDGEMENTS}

The Australian Ovarian Cancer Study Management Group (D Bowtell, G Chenevix-Trench, A deFazio, D Gertig, A Green, P Webb) and ACS Investigators (A Green, P Parsons, N Hayward, $\mathrm{P}$ Webb, D Whiteman) thank all the clinical and scientific collaborators (see http://www.aocstudy.org/) and the women for their contribution. The German Ovarian Cancer Study (GER) thank Ursula Eilber for competent technical assistance. AN Minlikeeva was supported by Interdisciplinary Training Grant in Cancer Epidemiology National Cancer Institute (NCI)(R25CA113951); JL Freudenheim was supported by National Institute of Health ( NIH)/NCI (2R25CA113951); G Friel was supported by NIH/NCI (R01CA095023 and R01CA126841); KH Eng was supported by NIH/NLM (K01LM012100) and the Roswell Park Alliance Foundation; JB Szender was supported by 5T32CA108456; BH Segal was supported by NIH (R01CA188900); KB Moysich is supported by P50CA159981 and
Roswell Park Alliance Foundation, NIH/NCI (R01CA095023, 2R25CA113951, and R01CA126841); AUS was supported by US Army Medical Research and Materiel Command (DAMD17-01-10729), National Health \& Medical Research Council of Australia (199600 and 400281), Cancer Councils of New South Wales, Victoria, Queensland, South Australia and Tasmania, Cancer Foundation of Western Australia; DOV was supported by NIH (R01 CA112523 and R01 CA87538); GER was supported by German Federal Ministry of Education and Research, Programme of Clinical Biomedical Research (01 GB 9401), and German Cancer Research Center; HAW was supported by NIH (R01 CA58598, N01 CN-55424 and N01 PC-67001); HJO was supported by Intramural funding and Rudolf-Bartling Foundation; HOP was supported by Department of Defense (DOD): DAMD17-02-1-0669 and NCI (K07-CA080668, R01-CA95023, P50-CA159981, R01CA126841); JPN was supported by Grant-in-Aid for the Third Term Comprehensive 10-Year Strategy for Cancer Control from the Ministry of Health, Labour and Welfare; LAX was supported by American Cancer Society Early Detection Professorship (SIOP06-258-01-COUN) and the National Center for Advancing Translational Sciences (NCATS), Grant UL1TR000124; NCO was supported by NIH (R01-CA76016) and the DOD (DAMD17-02-10666); NEC was supported by NIH (R01-CA54419 and P50CA105009) and DOD (W81XWH-10-1-02802; NJO was supported by NIH (K07 CA095666, R01-CA83918, K22-CA138563, and P30CA072720) and the Cancer Institute of New Jersey.

\section{CONFLICT OF INTEREST}

The authors declare no conflict of interest.

\section{REFERENCES}

Bandera EV, King M, Chandran U, Paddock LE, Rodriguez-Rodriguez L, Olson SH (2011) Phytoestrogen consumption from foods and supplements and epithelial ovarian cancer risk: a population-based case control study. BMC Womens Health 11: 40. 
Bodelon C, Cushing-Haugen KL, Wicklund KG, Doherty JA, Rossing MA (2012) Sun exposure and risk of epithelial ovarian cancer. Cancer Causes Control 23(12): 1985-1994.

Brinton LA, Sakoda LC, Frederiksen K, Sherman ME, Kjaer SK, Graubard BI, Olsen JH, Mellemkjaer L (2007) Relationships of uterine and ovarian tumors to pre-existing chronic conditions. Gynecol Oncol 107(3): 487-494.

Burch HB, Cooper DS (2015) Management of Graves disease: a review. JAMA 314(23): 2544-2554.

Cannioto R, LaMonte MJ, Risch HA, Hong CC, Sucheston-Campbell LE, Eng KH, Szender JB, Chang-Claude J, Schmalfeldt B, Klapdor R, Gower E, Minlikeeva AN, Zirpoli GR, Bandera EV, Berchuck A, Cramer D, Doherty JA, Edwards RP, Fridley BL, Goode EL, Goodman MT, Hogdall E, Hosono S, Jensen A, Jordan S, Kjaer SK, Matsuo K, Ness RB, Olsen CM, Olson SH, Pearce CL, Pike MC, Rossing MA, Szamreta EA, Thompson PJ, Tseng CC, Vierkant RA, Webb PM, Wentzensen N, Wicklund KG, Winham SJ, Wu AH, Modugno F, Schildkraut JM, Terry KL, Kelemen LE, Moysich KB, Group AOCS (2016) Chronic recreational physical inactivity and epithelial ovarian cancer risk: evidence from the Ovarian Cancer Association Consortium. Cancer Epidemiol Biomarkers Prev 25(7): 1114-1124.

Chandran U, Bandera EV, Williams-King MG, Paddock LE, Rodriguez-Rodriguez L, Lu SE, Faulkner S, Pulick K, Olson SH (2011) Healthy eating index and ovarian cancer risk. Cancer Causes Control 22(4): 563-571.

Gifkins D, Olson SH, Paddock L, King M, Demissie K, Lu SE, Kong AN, Rodriguez-Rodriguez L, Bandera EV (2012) Total and individual antioxidant intake and risk of epithelial ovarian cancer. BMC Cancer 12: 211 .

Goodman MT, Lurie G, Thompson PJ, McDuffie KE, Carney ME (2008) Association of two common single-nucleotide polymorphisms in the CYP19A1 locus and ovarian cancer risk. Endocr Relat Cancer 15(4): 1055-1060.

Hamajima N, Matsuo K, Saito T, Hirose K, Inoue M, Takezaki T, Kuroishi T, Tajima K (2001) Gene-environment interactions and polymorphism studies of cancer risk in the hospital-based epidemiologic research program at Aichi Cancer Center II (HERPACC-II). Asian Pac J Cancer Prev 2(2): 99-107.

Higgins JP, Thompson SG, Deeks JJ, Altman DG (2003) Measuring inconsistency in meta-analyses. BMJ 327(7414): 557-560.

Hu X, Li D, Zhang W, Zhou J, Tang B, Li L (2012) Matrix metalloproteinase-9 expression correlates with prognosis and involved in ovarian cancer cell invasion. Arch Gynecol Obstet 286(6): 1537-1543.

Journy NM, Bernier MO, Doody MM, Alexander BH, Linet M, Kitahara CM (2017) Hyperthyroidism, hypothyroidism and cause-specific mortality in a large cohort of women. Thyroid 7(8): 1001-1010.

Kang JH, Kueck AS, Stevens R, Curhan G, De Vivo I, Rosner B, Alexander E, Tworoger SS (2013) A large cohort study of hypothyroidism and hyperthyroidism in relation to gynecologic cancers. Obstet Gynecol Int 2013: 743721

Lee JS, Choi YD, Lee JH, Nam JH, Choi C, Lee MC, Park CS, Juhng SW, Min KW (2006) Expression of cyclooxygenase-2 in epithelial ovarian tumors and its relation to vascular endothelial growth factor and p53 expression. Int J Gynecol Cancer 16(Suppl 1): 247-253.

Lo-Ciganic WH, Zgibor JC, Bunker CH, Moysich KB, Edwards RP, Ness RB (2012) Aspirin, nonaspirin nonsteroidal anti-inflammatory drugs, or acetaminophen and risk of ovarian cancer. Epidemiology 23(2): 311-319.

Lurie G, Wilkens LR, Thompson PJ, McDuffie KE, Carney ME, Terada KY, Goodman MT (2008) Combined oral contraceptive use and epithelial ovarian cancer risk: time-related effects. Epidemiology 19(2): 237-243.

Mascarenhas C, Lambe M, Bellocco R, Bergfeldt K, Riman T, Persson I, Weiderpass E (2006) Use of hormone replacement therapy before and after ovarian cancer diagnosis and ovarian cancer survival. Int $J$ Cancer 119(12): 2907-2915.

Merritt MA, De Pari M, Vitonis AF, Titus LJ, Cramer DW, Terry KL (2013) Reproductive characteristics in relation to ovarian cancer risk by histologic pathways. Hum Reprod 28(5): 1406-1417.

Merritt MA, Green AC, Nagle CM, Webb PM (2008) Talcum powder, chronic pelvic inflammation and NSAIDs in relation to risk of epithelial ovarian cancer. Int J Cancer 122(1): 170-176.

Minlikeeva AN, Freudenheim JL, Cannioto RA, Szender JB, Eng KH, Modugno F, Ness RB, LaMonte MJ, Friel G, Segal BH, Odunsi K, Mayor P,
Zsiros E, Schmalfeldt B, Klapdor R, Dörk T, Hillemanns P, Kelemen LE, Köbel M, Steed H, de Fazio A, Jordan SJ, Nagle CM, Risch HA, Rossing MA, Doherty JA, Goodman MT, Edwards R, Matsuo K, Mizuno M, Karlan BY, Kjær SK, Høgdall E, Jensen A, Schildkraut JM, Terry KL, Cramer DW, Bandera EV, Paddock LE, Kiemeney LA, Massuger LF, Kupryjanczyk J, Berchuck A, Chang-Claude J, Diergaarde B, Webb PM, Moysich KB, Group AOCS, Consortium OCA (2017) History of hypertension, heart disease, and diabetes and ovarian cancer patient survival: evidence from the ovarian cancer association consortium. Cancer Causes Control 28(5): 469-486.

Ness RB, Grisso JA, Cottreau C, Klapper J, Vergona R, Wheeler JE, Morgan M, Schlesselman JJ (2000) Factors related to inflammation of the ovarian epithelium and risk of ovarian cancer. Epidemiology 11(2): 111-117.

Rae MT, Gubbay O, Kostogiannou A, Price D, Critchley HO, Hillier SG (2007) Thyroid hormone signaling in human ovarian surface epithelial cells. J Clin Endocrinol Metab 92(1): 322-327.

Rodriguez C, Calle EE, Coates RJ, Miracle-McMahill HL, Thun MJ, Heath CW (1995) Estrogen replacement therapy and fatal ovarian cancer. Am J Epidemiol 141(9): 828-835.

Rossing MA, Cushing-Haugen KL, Wicklund KG, Doherty JA, Weiss NS (2007) Menopausal hormone therapy and risk of epithelial ovarian cancer. Cancer Epidemiol Biomarkers Prev 16(12): 2548-2556.

Royar J, Becher H, Chang-Claude J (2001) Low-dose oral contraceptives: protective effect on ovarian cancer risk. Int J Cancer 95(6): 370-374.

Schildkraut JM, Iversen ES, Wilson MA, Clyde MA, Moorman PG, Palmieri RT, Whitaker R, Bentley RC, Marks JR, Berchuck A (2010) Association between DNA damage response and repair genes and risk of invasive serous ovarian cancer. PLoS ONE 5(4): e10061.

Schildkraut JM, Moorman PG, Bland AE, Halabi S, Calingaert B, Whitaker R, Lee PS, Elkins-Williams T, Bentley RC, Marks JR, Berchuck A (2008) Cyclin $\mathrm{E}$ overexpression in epithelial ovarian cancer characterizes an etiologic subgroup. Cancer Epidemiol Biomarkers Prev 17(3): 585-593.

Schrepf A, Thaker PH, Goodheart MJ, Bender D, Slavich GM, Dahmoush L, Penedo F, DeGeest K, Mendez L, Lubaroff DM, Cole SW, Sood AK, Lutgendorf SK (2015) Diurnal cortisol and survival in epithelial ovarian cancer. Psychoneuroendocrinology 53: 256-267.

Shinderman-Maman E, Cohen K, Weingarten C, Nabriski D, Twito O, Baraf L, Hercbergs A, Davis PJ, Werner H, Ellis M, Ashur-Fabian O (2015) The thyroid hormone- $\alpha \mathrm{v} \beta 3$ integrin axis in ovarian cancer: regulation of gene transcription and MAPK-dependent proliferation. Oncogene 35: 1977-1987.

Siegel RL, Miller KD, Jemal A (2017) Cancer statistics, 2017. CA Cancer J Clin 67(1): 7-30

Song H, Ramus SJ, Tyrer J, Bolton KL, Gentry-Maharaj A, Wozniak E, Anton-Culver H, Chang-Claude J, Cramer DW, DiCioccio R, Dork T, Goode EL, Goodman MT, Schildkraut JM, Sellers T, Baglietto L, Beckmann MW, Beesley J, Blaakaer J, Carney ME, Chanock S, Chen Z, Cunningham JM, Dicks E, Doherty JA, Durst M, Ekici AB, Fenstermacher D, Fridley BL, Giles G, Gore ME, De Vivo I, Hillemanns P, Hogdall C, Hogdall E, Iversen ES, Jacobs IJ, Jakubowska A, Li D, Lissowska J, Lubinski J, Lurie G, McGuire V, McLaughlin J, Medrek K, Moorman PG, Moysich K, Narod S, Phelan C, Pye C, Risch H, Runnebaum IB, Severi G, Southey M, Stram DO, Thiel FC, Terry KL, Tsai YY, Tworoger SS, Van Den Berg DJ, Vierkant RA, Wang-Gohrke S, Webb PM, Wilkens LR, Wu AH, Yang H, Brewster W, Ziogas A, Houlston R, Tomlinson I, Whittemore AS, Rossing MA, Ponder BA, Pearce CL, Ness RB, Menon U, Kjaer SK, Gronwald J, Garcia-Closas M, Fasching PA, Easton DF, Chenevix-Trench G, Berchuck A, Pharoah PD, Gayther SA (2009) A genome-wide association study identifies a new ovarian cancer susceptibility locus on 9p22.2. Nat Genet 41(9): 996-1000.

Terry KL, De Vivo I, Titus-Ernstoff L, Shih MC, Cramer DW (2005) Androgen receptor cytosine, adenine, guanine repeats, and haplotypes in relation to ovarian cancer risk. Cancer Res 65(13): 5974-5981.

This work is published under the standard license to publish agreement. After 12 months the work will become freely available and the license terms will switch to a Creative Commons AttributionNonCommercial-Share Alike 4.0 Unported License. 
${ }^{1}$ Deparment of Cancer Prevention and Control, Roswell Park Cancer Institute, Elm and Carlton Streets, Buffalo, NY 14263, USA; ${ }^{2}$ Deparment of Epidemiology and Environmental Health, University at Buffalo, 270 Farber Hall, University at Buffalo, Buffalo, NY 14214-8001, USA; ${ }^{3}$ Department of Biostatistics and Bioinformatics, Roswell Park Cancer Institute, Elm and Carlton Streets, Buffalo, NY 14263, USA; ${ }^{4}$ Department of Surgery, Division of Gynecologic Oncology, Roswell Park Cancer Institute, Elm and Carlton Streets, Buffalo, NY 14263, USA; ${ }^{5}$ Obstetrics and Gynecology Epidemiology Center, Brigham and Women's Hospital, 221 Longwood Avenue RFB 368, Boston, MA 02115, USA; ${ }^{6}$ Department of Epidemiology, Graduate School of Public Health, University of Pittsburgh, and University of Pittsburgh Cancer Institute, 435 Cancer Pavillion, University of Pittsburgh Cancer Institute, 5117 Centre Avenue, Pittsburgh, PA 15213, USA; ${ }^{7}$ Department of Epidemiology, The Geisel School of Medicine at Dartmouth College, One Medical Center Drive, Rubin Building, Room 853, HB 7927, Lebanon, NH 03756, USA; ${ }^{8}$ Department of Obstetrics and Gynecology, Hannover Medical School, Hannover Medical School, OE 6411, Hannover D-30625, Germany; ${ }^{9}$ Division of Gynecologic Oncology, Department of Obstetrics, Gynecology and Reproductive Sciences, University of Pittsburgh School of Medicine, Pittsburgh, PA, USA; ${ }^{10}$ Ovarian Cancer Center of Excellence, Womens Cancer Research Program, Magee-Womens Research Institute and University of Pittsburgh Cancer Institute, Magee-Womens Hospital, 300 Halket Street, Room 2130 , Pittsburgh, PA 15222, USA; ${ }^{11}$ Department of Gynecological Oncology, Westmead Hospital and the Westmead Institute for Medical Research, The University of Sydney, Centre for Cancer Research, The Westmead Institute for Medical Research, 176 Hawkesbury Road, Sydney/Westmead, NSW 2145, Australia; ${ }^{12}$ Cancer Prevention and Control, Samuel Oschin Comprehensive Cancer Institute, Cedars-Sinai Medical Center, 8700 Beverly Boulevard, Room 1S37, Los Angeles, CA 90048, USA; ${ }^{13}$ Department of Virus, Lifestyle and Genes, Danish Cancer Society Research Center, Strandboulevarden 49, Copenhagen O DK-2100, Denmark; ${ }^{14}$ Department of Pathology, Herlev and Gentofte Hospital, University of Copenhagen, Copenhagen, Denmark; ${ }^{15}$ Population Health Department, QIMR Berghofer Medical Research Institute, 300 Herston Road, Brisbane/Herston, QLD 4006, Australia; ${ }^{16}$ Women's Cancer Program at the Samuel Oschin Comprehensive Cancer Institute, Cedars-Sinai Medical Center, 8635 West Third Street, Suite 290, Los Angeles, CA 90048, USA; ${ }^{17}$ Deparment of Gynaecology, Rigshospitalet, University of Copenhagen, Copenhagen, Denmark; ${ }^{18}$ Division of Molecular Medicine, Aichi Cancer Center Research Institute, 1-1 Kanokoden, Chikusa-ku, Nagoya 464-8681, Japan; ${ }^{19}$ Department of Gynecological Oncology, Aichi Cancer Center Hospital, 1-1 Kanokoden, Chikusa-ku, Nagoya 464-8681, Japan; ${ }^{20}$ The University of Queensland, School of Public Health, 300 Herston Road, Brisbane/Herston, QLD 4006, Australia; ${ }^{21}$ Center of Immunotherapy, Roswell Park Cancer Institute, Elm and Carlton Streets, Buffalo, NY 14263, USA; ${ }^{22}$ New Jersey Department of Health and Senior Services, 12D Quarkerbridge Plaza, Trenton/Mercerville, NJ 08619, USA; ${ }^{23}$ School of Public Health, University of Medicine and Dentistry of New Jersey, Piscataway, NJ, USA; ${ }^{24}$ Program in Epidemiology, Division of Public Health Sciences, Fred Hutchinson Cancer Research Center, M4 C308, 1100 Fairview Avenue N, Seattle, WA, 98109, USA; ${ }^{25}$ Department of Public Health Sciences, School of Medicine, University of Virginia, The University of Virginia, Box 800717, Charlotteville, VA 22908, USA; ${ }^{26}$ Department of Gynecology, University Medical Center Hamburg-Eppendorf, Martinistrasse 52, 20246 Hamburg, Germany; ${ }^{27}$ Department of Medicine, Roswell Park Cancer Institute, Elm and Carlton Streets, Buffalo, NY 14263, USA; ${ }^{28}$ Department of Immunology, Roswell Park Cancer Institute, Elm and Carlton Streets, Buffalo, NY 14263, USA; ${ }^{29}$ School of Public Health, The University of Texas, The University of Texas School of Public Health, 1200 Herman Pressler, Suite W130, Houston, TX 77030, USA; ${ }^{30}$ Department of Obstetrics, Gynecology and Reproductive Sciences and Department of Epidemiology, University of Pittsburgh, Pittsburgh, PA, USA; ${ }^{31}$ Cancer Prevention and Control Program, Rutgers Cancer Institute of New Jersey, The State University of New Jersey, 195 Little Albany Street, Room 5568, New Brunswick, NJ 08903, USA; ${ }^{32}$ Division of Cancer Epidemiology, German Cancer Research Cancer, Im Neuenheimer Feld 581, 69120 Heidelberg; Germany and ${ }^{33}$ University Cancer Center Hamburg (UCCH), University Medical Center Hamburg-Eppendorf, Hamburg, Germany 